Tropical Journal of Pharmaceutical Research March 2019; 18 (3): 471-477

ISSN: 1596-5996 (print); 1596-9827 (electronic)

(C) Pharmacotherapy Group, Faculty of Pharmacy, University of Benin, Benin City, 300001 Nigeria.

\title{
Synergistic anti-cancer activity of combined 5-fuorouracil and gallic acid-stearylamine conjugate in A431 human squamous carcinoma cell line
}

\author{
R Rajagopalan ${ }^{1 *}$, Sanjay K Jain ${ }^{2}$, Piyush Trivedi ${ }^{1}$ \\ ${ }^{1}$ Department of Pharmaceutics, School of Pharmaceutical Sciences, Rajiv Gandhi Technological University, Bhopal (M.P.), \\ ${ }^{2}$ Department of Pharmaceutics, Dr. Harisingh Gour University, Sagar (M.P.), India
}

*For correspondence: Email: rajagopalan10@gmail.com; Tel: +91-9179626663

Sent for review: 29 May 2018

Revised accepted: 20 February 2019

\begin{abstract}
Purpose: To evaluate the individual and synergistic anti-cancer effects of 5-fuorouracil (5-FU) and synthesized gallic acid-stearylamine (GA-SA) conjugate in A431 human squamous cancer cell line. Methods: Characterisation of the synthesised conjugate was performed using Fourier transform infrared spectroscopy (FT-IR), nuclear magnetic resonance (NMR), and mass spectrometry (MS). The synergistic effect of the combination therapy (5-FU/GA-SA) was assessed by determining their inhibitory concentration $\left(I C_{30}\right)$ whereby A431 cells were treated with 5-FU:GA-SA conjugate at various ratios ranging from 5:1 to 1:5.

Results: The cytotoxicity of 5-FU was $29 \%$, while that of the combination of 5-FU with GA-SA conjugate was as high as $60 \%$. Thus, this combination showed significant synergistic enhancement in cytotoxicity $(p<0.05)$. The results obtained also revealed that the $I C_{30}$ values of 5-FU and the GA-SA conjugate were 1 and $10 \mu \mathrm{g} / \mathrm{mL}$, respectively. The $I_{30}$ values of the combination ratios indicated that the dosages used in the study were safe in HaCaT normal cell line.

Conclusion: These results indicate that 5-FU/GA-SA conjugate at a ratio of 1:1 is effective against A431 cell line (cancer cells)) but safe in HaCaT cell lines (normal cells).
\end{abstract}

Keywords: 5-Flurouracil, Gallic acid, Stearylamine, Skin cancer, Cytotoxicity, Synergism

\begin{abstract}
This is an Open Access article that uses a funding model which does not charge readers or their institutions for access and distributed under the terms of the Creative Commons Attribution License (http://creativecommons.org/licenses/by/4.0) and the Budapest Open Access Initiative (http://www.budapestopenaccessinitiative.org/read), which permit unrestricted use, distribution, and reproduction in any medium, provided the original work is properly credited.
\end{abstract}

Tropical Journal of Pharmaceutical Research is indexed by Science Citation Index (SciSearch), Scopus, International Pharmaceutical Abstract, Chemical Abstracts, Embase, Index Copernicus, EBSCO, African Index Medicus, JournalSeek, Journal Citation Reports/Science Edition, Directory of Open Access Journals (DOAJ), African Journal Online, Bioline International, Open-J-Gate and Pharmacy Abstracts

\section{INTRODUCTION}

Skin cancer is a tumour formed from the uncontrolled growth of abnormal skin cells. It has a multifactorial aetiology involving genetic alterations, environmental factors, and lifestyle factors. 5-Fluorouracil (5-FU) is an anticancer drug that suppresses the activity of thymidylate synthetase. However, the use of 5-FU has many disadvantages. One of these drawbacks is that
5-FU leads to inactivation of dihydropyrimidine dehydrogenase, thereby reducing its absorption through the gastrointestinal tract. Other disadvantages include its short half-life and toxic effects on the bone marrow and normal cells. Scientists have attempted to improve the efficacy of this drug by increasing its circulation period and minimising its side effects by localising the drug to the affected cells through targeted approaches [1,2]. 
Gallic acid (GA; 3, 4, 5-trihydroxy benzoic acid) is a naturally occurring polyphenolic group found in many plants either as free GA or gallotannins, which are the glucose-esterified products of GA . Gallic acid (GA) possesses remarkable antioxidant [3], anti-inflammatory and anticarcinogenic [4], and antifungal properties [5]. These properties may be enhanced by the conjugation of GA to stearylamine (SA), forming GA-SA amide conjugate. This conjugation also initially increases the solubility of $\mathrm{GA}$ within a mixture of solvents. Thus, in future, the conjugate is most likely to be used in the formulation of lipid-based carriers for the vesicular system: greater entrapment of GA induces higher GA uptake by cells [6]. The present study investigates the synergistic cytotoxic activity of the combination of GA-SA conjugate with 5-FU in A431 human squamous carcinoma cell line.

\section{EXPERIMENTAL}

\section{Chemicals}

Gallic acid (GA), Stearylamine (SA), Tris-(2, 2, 2trifluoroethyl)borate, Amberlyst A-26(OH), Amberlyst 15, Amberlite IRA743, and 5-FU were procured from Sigma Aldrich Pvt Ltd, Bengaluru, India). A431 human squamous carcinoma cell line and normal $\mathrm{HaCaT}$ human immortalised keratinocyte cell line were obtained from the National Centre for Cell Science (NCCS), Pune, India. Dulbecco's modified Eagle's medium (DMEM), streptomycin, penicillin and foetal bovine serum (FBS) were brought from Himedia
Laboratories Pvt Ltd, Mumbai, India. Ethylene diamine tetra acetic acid (EDTA), 3-(4,5dimethylthiazol-2-yl)-2,5-diphenyl tetrazolium bromide (MTT), dimethyl sulfoxide (DMSO) and trypsin were procured from Sigma Aldrich Pvt Ltd, Bengaluru, India.

\section{Preparation of gallic acid-stearylamine conjugate}

In the present study all reactions were achieved on a 1-mmol scale. Tris-(2,2,2-trifluoroethyl) borate (chemical formula: $\mathrm{B}\left(\mathrm{OCH}_{2} \mathrm{CF}_{3}\right)_{3} ; 2 \mathrm{mmol}$, 2 equiv) was added to a solution of $\mathrm{GA}$ ( $1 \mathrm{mmol}$, 1 equiv) whereas $\mathrm{SA}$ ( $1 \mathrm{mmol}, 1$ equiv) was prepared in acetonitrile $(2 \mathrm{~mL}, 0.5 \mathrm{M})$. Then the reaction mixture was stirred at $80{ }^{\circ} \mathrm{C}$ in a properly sealed carousel tube for $5 \mathrm{~h}$. Figure. 1 shows the chemical reaction of gallic acid (GA)stearylamine (SA) conjugate.

\section{Solid stage workup}

At the end of the reaction ( $5 \mathrm{~h}$ ), the mixture was diluted with $\mathrm{CH}_{2} \mathrm{Cl}_{2}(3 \mathrm{~mL})$ and water $(0.5 \mathrm{~mL})$. Amberlyst $15(150 \mathrm{mg})$, Amberlyst $\mathrm{A}-26(\mathrm{OH})$ $(150 \mathrm{mg})$, and Amberlite IRA743 (150 mg) were added to the mixture and stirred for $30 \mathrm{~min}$. Then, $\mathrm{MgSO}_{4}$ was added and thereafter, the mixture was filtered. To produce the amide product, the solids obtained were separated from $\mathrm{CH}_{2} \mathrm{Cl}_{2}$ three times through concentration in vacuo [7].

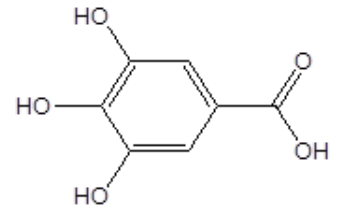

Gallic acid

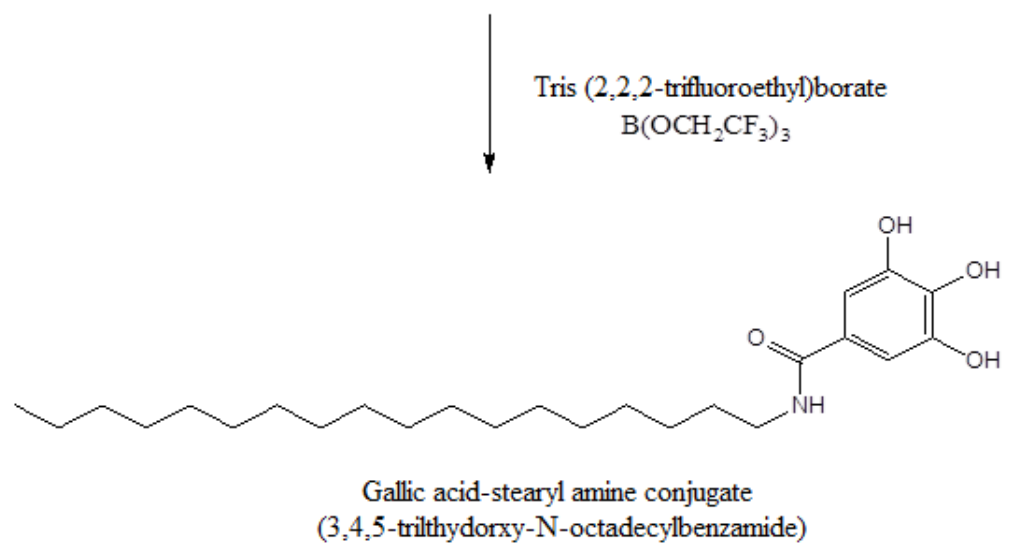

Figure 1: Chemical reactions involved in the preparation of gallic acid-stearylamine conjugate 


\section{Fourier transform infrared spectrometry (FT- IR)}

FT-IR spectra of the test compounds were generated using a Shimadzu Prestige 21 FT-IR spectrometer through the $\mathrm{KBr}$ approach. The spectra were determined between 4000 and 400 $\mathrm{cm}^{-1}$.

\section{Nuclear magnetic resonance (NMR)}

Proton nuclear magnetic resonance ( ${ }^{1} \mathrm{H}$ NMR) spectra were obtained using a Bruker Ultra shield $(400 \mathrm{MHz})$ spectrometer.

\section{Mass spectrometry (MS)}

The MASS spectra of the test compounds were generated in ESI-MS mode on a MicroTOF-Q-II instrument (Bruker Daltonics).

\section{Determination of cytotoxic concentrations of test compounds}

The cytotoxic activities of the test compounds (5FU and the GA-SA conjugate) were evaluated against A431 human squamous carcinoma cell line. The cells were trypsinized and counted using Trypan blue method within Neubauer chamber, and they were plated in a flat bottom 96-well plate at a density of $8 \times 10^{3}$ cells/well $/ 180$ $\mu \mathrm{L}$ media. Following overnight incubation, the cells were treated with the test compounds (20 $\mu \mathrm{L} /$ well) at concentrations ranging from 0.1 to $100 \mu \mathrm{g} / \mathrm{mL}$. Subsequently the volume of each well was made up to a $200 \mu \mathrm{L}$. Untreated cells were considered as negative control. After treatment, the cells were placed in a $5 \% \mathrm{CO}_{2}$ incubator for $48 \mathrm{~h}$. The effect of the test compounds on cell viability was determined by MTT assay. In this assay, $20 \mu \mathrm{L}$ of $5 \mathrm{mg} / \mathrm{mL}$ MTT was added to each wells, and the wells were incubated at $37^{\circ} \mathrm{C}$ for $3 \mathrm{~h}$. Each supernatant was aspirated, and $150 \mu \mathrm{L}$ of DMSO was added to all wells to dissolve the formazan crystals formed. The absorbance of each well was read at $540 \mathrm{~nm}$ on a Biotek Reader. The cytotoxicity index was calculated using the untreated cells as negative control, and $\mathrm{IC}_{30}$ values were calculated using Graph Pad Prism version 5 software. The percentage cytotoxicity was calculated using the background-corrected absorbance, as in shown in Eq 1 [8].

$C=\{1-(A / B)\} 100$

where $A$ and $B$ are the absorbance values of experimental well and negative control well respectively and $\mathrm{C}$ is the percentage cytotoxicity.
Determination of anticancer efficacy of combination of 5-FU and GA-SA conjugate

The anticancer efficacy of the combination of the test compounds (5-FU and the GA-SA conjugate) was evaluated using A431 cell line and was determined based on the percentage cytotoxicity of the test compounds. The cells were trypsinized using Trypan blue method in Neubauer chamber, and plated in a 96-well plate at a density of $8 \times 10^{3} \mathrm{cells} / \mathrm{well} / 180 \mu \mathrm{L}$ media. Following overnight incubation, the cells were treated with the test compounds $(20 \mu \mathrm{L} /$ well $)$ at the ratios of $5: 1,4: 1,3: 1,2: 1,1: 1,1: 2,1: 3,1: 4$, and $1: 5$, in a total volume of $200 \mu \mathrm{L}$ in each well. Untreated cells served as negative control. Cells treated with DMSO $(0.1-0.5 \%)$ were considered as vehicle group. After treatment, the cells were placed in a $5 \% \mathrm{CO}_{2}$ incubator for $48 \mathrm{~h}$ [9].

\section{Determination of toxicity of test compounds}

The safety of the test compounds (5-FU and the GA-SA conjugate) was screened using $\mathrm{HaCaT}$ human immortalised keratinocyte cell line. The toxicity of the test compounds was investigated by MTT assay [8].

\section{Statistical analysis}

MTT assay results are expressed as mean \pm standard error of mean (SEM) of three replicates. The results were evaluated using Graph Pad Prism 5.0. All statistical analysis were done with Statistical Package for Social Sciences (SPSS) version 16.0, using one-way analysis of variance (ANOVA) and post hoc Tukey's test to determine differences between means. $P<0.05$ was considered statistically significant.

\section{RESULTS}

\section{Fourier transform infrared spectra}

Successful conjugation of GA with stearylamine was confirmed with FTIR spectra, as shown in Figure $2\left(\mathrm{KBr}\right.$ pellet, $\left.\mathrm{cm}^{-1}\right)$ : $3365-\mathrm{NH}$ stretching, $1708-\mathrm{C}=0$ stretching.

\section{Nuclear magnetic resonance spectra}

Figure 3 shows the ${ }^{1} \mathrm{H}$ NMR spectra of the GASA conjugate. The ${ }^{1} \mathrm{H}$ NMR $\left(\mathrm{d}_{6}-\mathrm{DMSO}\right)$ results were as follows:

${ }^{1} \mathrm{H}$ NMR $400 \mathrm{MHz}\left(\mathrm{d}_{6}\right.$-DMSO, $\left.\delta \mathrm{ppm}\right): 12.16$ $\left(\mathrm{OH}_{\mathrm{a}}, 2 \mathrm{H}, \mathrm{br}\right), 9.14$ ( $\mathrm{NH}$ of conjugate, $1 \mathrm{H}, \mathrm{S}$ ), 8.74-8.9 $\left(\mathrm{OH}_{\mathrm{b}}, 1 \mathrm{H}, \mathrm{br}\right), 7.6-7.84$ (aromatic $\mathrm{H}, \mathrm{S}$, $2 \mathrm{H}, \mathrm{m}$ ), 2.64-2.79 (methylene units of conjugate, 
$17 \mathrm{H}, \quad \mathrm{m}$ ), $1.42-1.55$ (methylene units of conjugate, $17 \mathrm{H}, \mathrm{m}), 0.80-0.83(3 \mathrm{H}, \mathrm{m}, \mathrm{Me} \mathrm{Hs}$ of the conjugate).

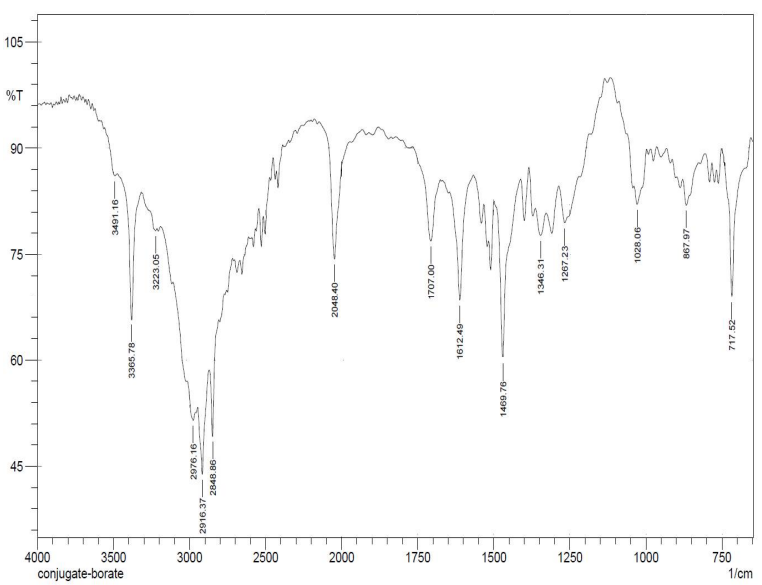

Figure 2: FTIR spectra of gallic acid-stearylamine conjugate

\section{Mass spectrometry}

Figure 4 shows the mass spectra of the synthesized GA-SA conjugate. Based on the ionisation method, the results were as follows:

$\mathrm{C}_{25} \mathrm{H}_{43} \mathrm{NO}_{4} \mathrm{M}^{+}=421$ (calculated), $\left[\mathrm{M}-\mathrm{H}^{+}\right]=420.5$ (actual).

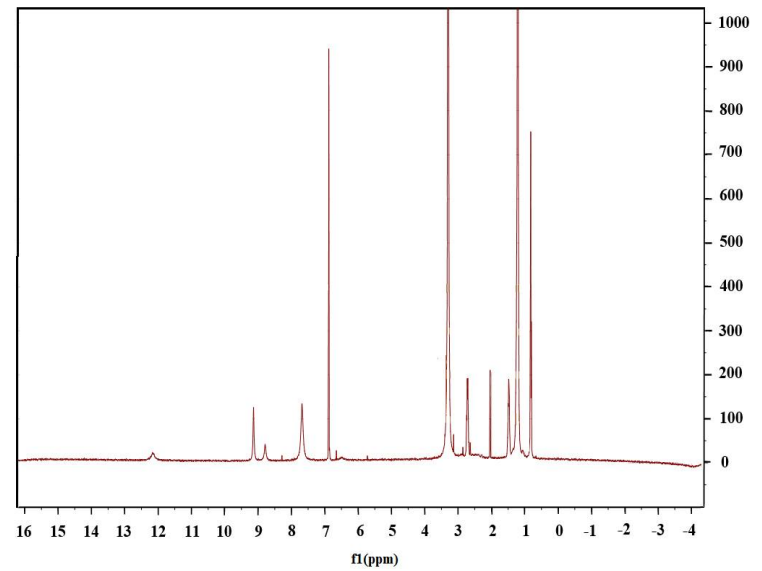

Figure 3: ${ }^{1} \mathrm{H}$ NMR spectra of gallic acid-stearylamine conjugate

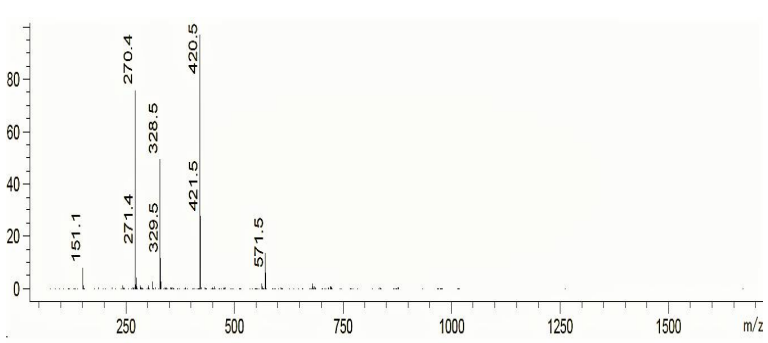

Figure 4: Mass spectra of gallic acid-stearylamine conjugate
Cytotoxic concentration of 5-FU and GA-SA conjugate

The cytotoxic activities of the test compounds (5FU and GA-SA conjugate) determined based on $I_{30}$ values, were to be 1 and $10 \mu \mathrm{g} / \mathrm{mL}$, respectively. The cytotoxicity data for the test compounds (5-FU and GA-SA conjugate) in A431 cell line are shown in Table 1, Table 2 and Figure 5.

\section{Anticancer efficacy of a combination of 5- FU/GA-SA conjugate in A431 cell line}

The combination ratios were selected based on the $\mathrm{IC}_{30}$ values obtained from the cytotoxic data of individual test compounds (5-FU and GA-SA conjugate) in $A 431$ cells. The $I_{30}$ values of individual test compounds were determined to obtain the optimal level of anticancer efficacy, i.e., at least $50 \%$ reduction $\left(\mathrm{IC}_{30}\right)$. The $\mathrm{A} 431$ cells were treated with different ratios of 5FU:GA-SA conjugate (ie, 5:1,4:1, 3:1,2:1, 1:1, $1: 2,1: 3,1: 4$ and 1:5; v/v). Table 3 and Figure 6 show the cytotoxicity values of the combination ratios of the test compounds (5-FU and GA-SA conjugate) in A431 cell line.

Table 1: Cytotoxicity of 5-fluorouracil in A431 cell line

\begin{tabular}{lcc}
\hline $\begin{array}{l}\text { Concentration } \\
(\boldsymbol{\mu g} / \mathrm{mL})\end{array}$ & $\begin{array}{c}\text { Absorbance } \\
(\mathrm{nm})^{\mathrm{a}}\end{array}$ & Cytotoxicity (\%) \\
\hline 0 & $0.626 \pm 0.07$ & 0.00 \\
0.1 & $0.601 \pm 0.04$ & 4.12 \\
1 & $0.446 \pm 0.05$ & 28.79 \\
5 & $0.418 \pm 0.08$ & 33.32 \\
10 & $0.373 \pm 0.07$ & 40.39 \\
50 & $0.236 \pm 0.02$ & 62.37 \\
100 & $0.170 \pm 0.01$ & 72.91 \\
\hline
\end{tabular}

Compared with negative control, 5-FU treatment showed statistically significant cytotoxicity $(p<0.05)$. ${ }^{a}$ Results are presented as mean \pm standard error of mean $(n=3) ;{ }^{b} 5$-fluorouracil

Table 2: Cytotoxicity of gallic acid-stearylamine conjugate in A431 cell line

\begin{tabular}{lcc}
\hline $\begin{array}{l}\text { Concentration } \\
(\boldsymbol{\mu g} / \mathrm{mL})\end{array}$ & $\begin{array}{c}\text { Absorbance } \\
(\mathbf{n m})^{\mathrm{a}}\end{array}$ & $\begin{array}{c}\text { Cytotoxicity } \\
(\%)\end{array}$ \\
\hline 0 & $0.626 \pm 0.07$ & 0.00 \\
0.1 & $0.543 \pm 0.12$ & -5.53 \\
1 & $0.633 \pm 0.12$ & 2.66 \\
5 & $0.546 \pm 0.04$ & 10.06 \\
10 & $0.503 \pm 0.03$ & 21.05 \\
50 & $0.228 \pm 0.06$ & 72.38 \\
100 & $0.185 \pm 0.02$ & 71.58 \\
\hline
\end{tabular}

Compared with negative control, GA-SA conjugate treatment showed statistically significant cytotoxicity $(p$ $<0.05)$. ${ }^{a}$ Results are presented as mean \pm standard error of mean $(n=3)$; ${ }^{b}$ gallic acid- stearylamine conjugate 


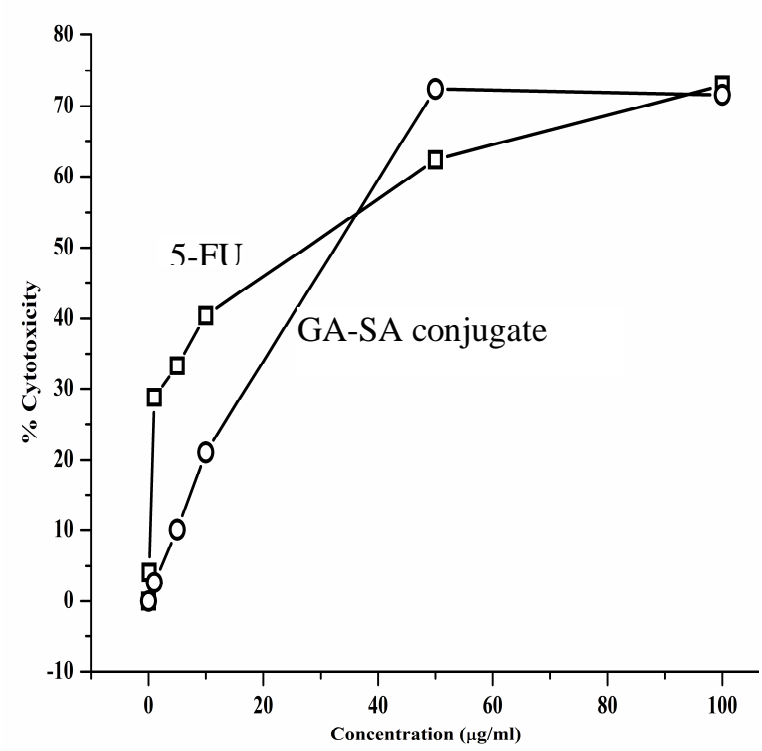

Figure 5: Cytotoxic effect of 5-FU and GA-SA conjugate on A431 cell line.

\section{Toxicity of 5-FU and GA-SA conjugate}

Table 4 shows the toxicity of $5-\mathrm{FU}$ in $\mathrm{HaCaT}$ cell line.

Table 3: Cytotoxicity of $5 \mathrm{FU}: \mathrm{GA}-\mathrm{SA}$ conjugate in A431 cell line

\begin{tabular}{lcc}
\hline $\begin{array}{l}\text { Combination } \\
\text { ratio }(\mu \mathrm{g} / \mathrm{mL})\end{array}$ & Absorbance $(\mathrm{nm})^{\mathrm{a}}$ & $\begin{array}{c}\text { Cytotoxicity } \\
(\%)\end{array}$ \\
\hline 0 & $1.903 \pm 0.15$ & 0.00 \\
$5: 1$ & $1.264 \pm 0.18$ & 40.94 \\
$4: 1$ & $0.896 \pm 0.10$ & 53.95 \\
$3: 1$ & $0.766 \pm 0.07$ & 57.05 \\
$2: 1$ & $0.954 \pm 0.05$ & 51.08 \\
$1: 1$ & $0.753 \pm 0.08$ & 60.29 \\
$1: 2$ & $0.633 \pm 0.07$ & 63.32 \\
$1: 3$ & $0.583 \pm 0.02$ & 68.94 \\
$1: 4$ & $0.693 \pm 0.03$ & 62.22 \\
$1: 5$ & $0.419 \pm 0.02$ & 77.93 \\
\hline
\end{tabular}

Compared with negative control, 5 FU:GA-SA conjugate treatment showed statistically significant cytotoxicity $(p<0.05)$. ${ }^{\mathrm{a}}$ Results are presented as mean \pm standard error of mean $(n=3)$; ${ }^{b} 5$ fluorouracil:gallic acid-stearylamine conjugate

\section{DISCUSSION}

5-Fluorouracil (5-FU) is a potent chemotherapeutic agent frequently chosen in combination therapy for the treatment of numerous cancers. However, the drug is disadvantaged by its short half-life and poor permeability in affected cells [10-12]. Consequently, significant research efforts have

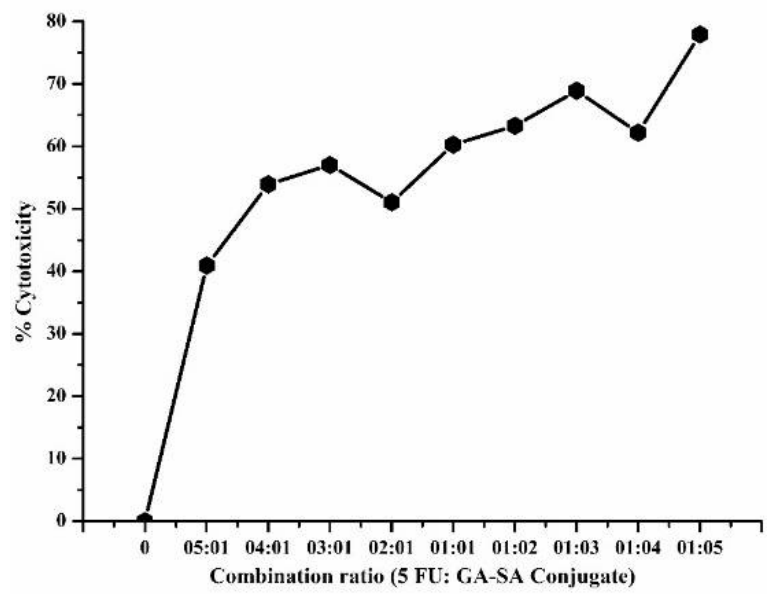

Figure 6: Cytotoxicity of various combinations of 5FU:GA-SA conjugate in A431 cells

Table 4: Cytotoxicity of 5-FU in HaCaT cell line

\begin{tabular}{lcc}
\hline $\begin{array}{l}\text { Concentration } \\
(\boldsymbol{\mu g} / \mathrm{mL})\end{array}$ & Absorbance $(\mathbf{n m})^{\mathrm{a}}$ & $\begin{array}{c}\text { Cytotoxicity } \\
(\%)\end{array}$ \\
\hline 0 & $0.699 \pm 0.13$ & 0.00 \\
0.01 & $0.612 \pm 0.12$ & 12.49 \\
0.1 & $0.526 \pm 0.07$ & 24.74 \\
1 & $0.565 \pm 0.14$ & 19.16 \\
5 & $0.309 \pm 0.04$ & 55.77 \\
10 & $0.418 \pm 0.07$ & 40.28 \\
50 & $0.193 \pm 0.03$ & 72.40 \\
100 & $0.188 \pm 0.00$ & 73.16 \\
\hline
\end{tabular}

${ }^{a}$ Results are presented as mean \pm standard error of mean $(n=3) .{ }^{b} 5$-Fluorouracil. The toxicity of GA-SA conjugate in HaCaT cell line is shown in Table 5

Table 5: Cytotoxicity of GA-SA conjugate in HaCaT cell line

\begin{tabular}{lcc}
\hline $\begin{array}{l}\text { Concentration } \\
(\boldsymbol{\mu} \mathbf{g} / \mathbf{m L})\end{array}$ & ${\text { Absorbance }(\mathbf{n m})^{\mathrm{a}}}^{\text {Cytotoxicity }}$ & $\begin{array}{c}\text { Co) } \\
(\%)\end{array}$ \\
\hline 0 & $0.699 \pm 0.13$ & 0.00 \\
0.01 & $0.668 \pm 0.09$ & 4.53 \\
0.1 & $0.495 \pm 0.07$ & 29.27 \\
1 & $0.948 \pm 0.06$ & -35.51 \\
5 & $0.596 \pm 0.09$ & 14.78 \\
10 & $0.530 \pm 0.00$ & 24.21 \\
50 & $0.243 \pm 0.06$ & 65.30 \\
100 & $0.300 \pm 0.06$ & 57.10 \\
\hline${ }^{a}$ Results are presented as mean \pm standard error of \\
\multicolumn{2}{c}{ mean $(\mathrm{n}=3) .{ }^{b}$ Gallic acid-stearylamine conjugate }
\end{tabular}

been directed towards enhancing the permeability, stability and half-life of the drug. With regard to permeability improvement, it was hypothesized in this study, that an adjuvant with long hydrocarbon chain would give the desired hydrophobicity for an optimal absorption of the drug molecule. It was also hoped that the chemical combination of such adjuvants with moieties possessing antioxidant and anticancer 
activities might help in obtaining desired synergistic cytotoxic activity against cancer cells. Therefore, this study set out to design a conjugate consisting of stearyl amine (possessing 18 methylene units) with gallic acid (known to possess antioxidant and anticancer activities against most cancer cell lines) as an optimal adjuvant formulation for 5FU.The choice of GA was based on the fact that it is known to be safe against normal skin cell line like HaCaT cells [13-15].

Besides, the proposed adjuvant should be cheap and easy to synthesize, such that the end formulation is economically feasible. In this study, GA-SA conjugate was synthesized using $\mathrm{B}\left(\mathrm{OCH}_{2} \mathrm{CF}_{3}\right)_{3}$-facilitated amidation reactions. Amide conjugate was considered in this case owing to its abundance in nature and its biocompatibility with many of the cancer chemotherapeutic agents $[6,16]$. The GA-SA synthesis was carried out in open air with equimolar concentration (1mmol) of carboxylic acid and amine, which are easily soluble in acetonitrile (MeCN). Moreover, since the present approach did not require separation with column chromatography, it was believed that GA-SA could be an eligible cost-effective substitute for 5 -FU topical formulations. The effectiveness of such a simple synthetic procedure was well reflected in the FTIR, NMR and MASS spectra of the resultant GA-SA conjugate $[16,17]$.

To test the efficacy of the synthesized GA-SA conjugate for the intended application i.e. topical formulations, two different cell lines viz. A431 and HaCat were chosen. The former is a widely used non-melanoma skin cancer cell line, while the latter is a well-known normal skin cell-line [18]. The cells were treated with GA-SA at different concentrations and the corresponding cytotoxicity results indicated that it was effective in cancer cell line and reasonably safe against normal cell lines. To test the efficacy of the produced GA-SA as a formulation adjuvant, cytotoxicity studies were conducted at different ratios of 5FU: GA-SA conjugate ranging from 5:1 - 1:5 (v/v), and significant synergistic cytotoxicity was observed against A431 cells at 1:1 ratio. It has been previously reported by several workers that synergism is dependent on the ratio of components [19, 20]. Importantly, it was observed that the cytotoxicity of the conjugate was as high as $60 \%$ at $0.1 \mu \mathrm{g} / \mathrm{ml}$ of $5-\mathrm{FU}$, in contrast to 5-FU when used alone. This indicates a 2 -fold increase in the anticancer activity of 5FU.

\section{CONCLUSION}

The results of this study show that $\mathrm{B}\left(\mathrm{OCH}_{2} \mathrm{CF}_{3}\right)_{3}$ mediates the conjugation of $\mathrm{GA}$ with stearylamine via an amide conjugate. Furthermore, the combination of 5-FU and GASA conjugate in a ratio of $1: 1(\mathrm{v} / \mathrm{v})$ is effectively cytotoxic against $A 431$ cancer cell line, but it is non-toxic against $\mathrm{HaCaT}$ normal cell line. Thus, the combination of the GA-SA conjugate and 5FU exerts synergistic anticancer effects in A431 cell line, and enhances the cytotoxicity of 5-FU, thereby achieving the desired therapeutic effects. The synergistic effect of 5-FU and GA-SA conjugate can thus minimise the clinical dosage of 5-FU, thereby reducing the toxicity associated with higher doses. Therefore, it may be suitable as an adjuvant in a topical formulation of 5-FU to improve permeation, localization of action and stability. However, further preclinical and clinical investigations are required to buttress these findings.

\section{DECLARATIONS}

\section{Acknowledgement}

The authors would like to thank Dr Ritu Verma for providing cytotoxicity MTT assay studies facilities at Dabur Research Foundation, Ghaziabad, Uttar Pradesh, India. All the authors acknowledge Mr Kamaraj Mani, Dabur Research Foundation, Ghaziabad, Uttar Pradesh, India and Dr Anita Dutt Konar and Dr Anindya Basu SOPS, RGPV, Bhopal for their valuable suggestions.

\section{Conflict of Interest}

No conflict of interest associated with this work.

\section{Contribution of Authors}

The authors declare that this work was done by the authors named in this article and all liabilities pertaining to claims relating to the content of this article will be borne by them.

\section{REFERENCES}

1. Yassin AEB, Anwer MK, Mowafy HA, El-Bagory IM, Bayomi MA, Alsarra IA. Optimization of 5-flurouracil solid-lipid nanoparticles: a preliminary study to treat colon cancer, Int J Med Sci 2010; 7: 398-408.

2. Li S, Wang A, Jiang W, Guan Z. Pharmacokinetic characteristics and anticancer effects of 5-Fluorouracil loaded nanoparticles. BMC Cancer 2008; 8: 103-121.

3. Da Rosa CG, Borges CD, Zambiazi RC, Nunes MR, Benvenutti EV, Da Luz SR, D’Avila RF Rutz JF. 
Microencapsulation of gallic acid in chitosan, $\beta$ cyclodextrin and xanthan. Industrial Crops Products 2013; 46: 138-146.

4. You BR, Moon HJ, Han YH, Park WH. Gallic acid inhibits the growth of HeLa cervical cancer cells via apoptosis and/or necrosis. Food Chem Toxicol 2010; 48: 13341340.

5. Kim JH, Kang NJ, Lee KB, Lee KW, Lee HJ. Gallic acid, a metabolite of the antioxidant propylgallate, inhibits gap junctional intercellular communication via phosphorylation of connexin 43 and extracellular-signalregulated kinase $1 / 2$ in rat liver epithelial cells. Mutation Res 2008; 638(1-2): 175-183.

6. Varshosaz J, Hassanzadeh F, Sadeghi H, Andalib S. Synthesis of octadecylamine-retinoic acid conjugate for enhanced cytotoxic effects of 5-FU using LDL targeted nanostructured lipid carriers. Euro J Med Chem 2012; 54: 429-438.

7. Lanigan RM, Starkov P, Sheppard TD. Direct Synthesis of Amides from Carboxylic Acids and Amines Using $\mathrm{B}\left(\mathrm{OCH}_{2} \mathrm{CF}_{3}\right)_{3}$. J Org Chem 2013; 78: 4512-4523.

8. Florento $L$, Matias $R$, Tuaño $E$, Santiago $K$, Cruz $F D$, Tuazon A. Comparison of Cytotoxic Activity of Anticancer Drugs against Various Human Tumor Cell Lines Using In Vitro Cell-Based Approach. Int $\mathrm{J}$ Biomed Sci 2012; 8(1): 76-80.

9. Wang $F$, Dai $W$, Wang $Y$, Shen $M$, Chen $K$, Cheng $P$, Zhang $Y$, Wang $C$, Li J, Zheng $Y$ et al. The Synergistic In Vitro and In Vivo Antitumor Effect of Combination Therapy with Salinomycin and 5-Fluorouracil against Hepatocellular Carcinoma. PLoS ONE 2014; 9 (5): 1-10.

10. Hwang JT, Ha J, Park OJ. Combination of 5-fluorouracil and genistein induces apoptosis synergistically in chemo-resistant cancer cells through the modulation of AMPK and COX-2 signaling pathways. Biochem Biophys Res Commun 2005; 32: 433-440.

11. Ming ZJ, Hu Y, Qiu YH, Cao L, Zhang XG. Synergistic effects of betaaescin and 5-fluorouracil in human hepatocellular carcinoma SMMC-7721 cells. Phytomed 2010; 17: 575-580.

12. Chen XX, Lai MD, Zhang YL, Huang Q. Less cytotoxicity to combination therapy of 5-fluorouracil and cisplatin than 5-fluorouracil alone in human colon cancer cell lines. World J Gastroenterol 2002; 8: 841-846.

13. Reddy TC, Reddy DB, Aparna A, Arunasree KM, Gupta G, Achari C, Reddy GV, Lakshmipathi V, Subramanyam A, Reddanna P. Anti-leukemic effects of gallic acid on human leukemia K562 cells: downregulation of COX-2, inhibition of $B C R / A B L$ kinase and NF-kappaB inactivation. Toxicol. In Vitro. 2012; 26: 396-405.

14. Hou AJ, Peng LY, Liu YZ, Lin ZW, Sun HD. Gallotannins and related polyphenols from Pistacia weinmannifolia. Planta Med. 2000; 66: 624-626.

15. Inoue M, Suzuki R, Sakaguchi N, Li Z, Takeda T, Ogihara $Y$, Jiang $B Y$, Chen $Y$. Selective induction of cell death in cancer cells by gallic acid. Biol. Pharm. Bull. 1995; 18: 1526-1530.

16. Varshosaz J, Hassanzadeh F, Sadeghi H, Khadem M. Galactosylated nanostructured lipid carriers for delivery of 5-FU to hepatocellular carcinoma. J Liposome Res 2012; 22(3): 224-236.

17. Pasanphan W, Buettner G R, Chirachanchai S. Chitosan gallate as a novel potential polysaccharide antioxidant: an EPR study. Carbohydrate Research 2010; 345: 132140.

18. Gupta V, Dhote V, Paul BN, Trivedi P. Development of novel topical drug delivery system containing cisplatin and imiquimod for dual therapy in cutaneous epithelial malignancy, J Liposome Res 2013; Early online: 1-13.

19. Chou TC. Theoretical basis, experimental design, and computerized simulation of synergism and antagonism in drug combination studies. Pharmacol. Rev. 2006; 58: 621-681.

20. Feng LZ, Li, Liu YJ, Yang SM, Zhang N. Synergistic Enhancement of Cancer Therapy Using a Combination of Ceramide and Docetaxel. Int. J. Mol. Sci. 2014; 15: 4201-4220. 